\title{
Kombinasi Artesunat Injeksi dan Ekstrak Brotowali (Tinospora crispa (L) Miers) Menurunkan Derajat Parasitemia serta Meningkatkan Ekspresi HSP70 dan Endoglin pada Mencit C57BL/6J yang Diinfeksi Plasmodium berghei
}

\section{Combination of Arthesunate Injection and Brotowali (Tinospora crispa (L) Miers) Extract Reduces Parasitemia Level and Increases HSP70 and Endoglin Expressions in C57BL/6J Mice Infected with Plasmodium berghei}

\author{
Rahadi Swastomo ${ }^{1}$, Niniek Budiarti', Loeki E Fitri ${ }^{3}$, Sri Poeranto ${ }^{3}$ \\ ${ }^{1}$ Fakultas Kedokteran Hewan Universitas Brawijaya Malang \\ ${ }^{2}$ Bagian Penyakit Dalam Rumah Sakit Daerah Umum Dr. Saiful Anwar Malang \\ ${ }^{3}$ Departemen Parasitologi Fakultas Kedokteran Universitas Brawijaya Malang
}

\begin{abstract}
ABSTRAK
Penemuan kombinasi terapi baru untuk malaria dianggap penting karena kemampuan resistensi dari Plasmodium terhadap pengobatan terdahulu. Sebanyak 18 mencit dibagi ke dalam kelompok kontrol negatif, kontrol positif, kelompok artesunat, serta kelompok kombinasi artesunat dengan brotowali (dosis 50 mg, 60 mg dan 70 mg). Selain kontrol negatif, semua mencit diinfeksi Plasmodium berghei. Selanjutnya diamati derajat parasitemianya sampai hari ke-7, kemudian dilakukan pemeriksaaan imunohistokimia guna mengetahui ekspresi HSP70 dan endoglin pada otak mencit. Kombinasi artesunat injeksi dan ekstrak brotowali terbukti dapat menurunkan derajat parasitemia lebih baik dari pemberian terapi tunggal artesunat dan meningkatkan ekspresi HSP70 dan endoglin. Kesimpulannya, kombinasi terapi malaria menggunakan artesunat dan brotowali terbukti berpotensi sebagai terapi kombinasi yang efektif terhadap malaria karena mampu menurunkan derajat parasitemia sampai 0\% dan meningkatkan ekspresi HSP70 dan endoglin pada otak mencit C57BL/6J secara signifikan.
\end{abstract}

Kata Kunci: Artesunat, brotowali, endoglin, HSP70, malaria, Plasmodium berghei

\begin{abstract}
The discovery of a new combination therapy for malaria is important because of the resistance of Plasmodium to the earlier treatment. A total of 18 mice were divided into negative control group, positive control, artesunate group, and combination of artesunate and brotowali groups (at doses of $50 \mathrm{mg}, 60 \mathrm{mg}$ and $70 \mathrm{mg}$ ), respectively. With the exception of negative control, all mice were infected with Plasmodium berghei. Furthermore, the degree of parasitemia was observed on the 7th day, then the expressions of HSP7O and endoglinin the mice brains were evaluated. The combination of arthesunate injection and brotowali extract was proven to reduce the degree of parasitaemia better than singlearthesunate therapy, and increase the expressions of HSP70 and endoglin. In conclusion, the combination of arthesunate and brotowali extract was proven as a potential combination therapy for malaria with ability to reduce the degree of parasitaemia to $0 \%$ and significantly increase the expressions of HSP7O and endoglin in the C57BL/6J mice brains.
\end{abstract}

Keywords: Arthesunate, brotowali, endoglin, HSP70, malaria, Plasmodium berghei

Korespondensi: Rahadi Swastomo. Fakultas Kedokteran Hewan Universitas Brawijaya, Jl. MT. Haryono 169 Malang-Jawa Timur Tel. (0341)2234838Email: rahadiswastomo@yahoo.co.id

DOI: http://dx.doi.org/10.21776/ub.jkb.2017.029.04.3 


\section{PENDAHULUAN}

World Health Organization (WHO) memperkirakan bahwa pada tahun 2010 kasus malaria telah menyebabkan kematian pada 660.000 sampai 1,2 juta manusia dan terutama adalah anak-anak di Afrika. Angka kematian sesungguhnya tidak diketahui secara pasti, kemungkinan karena ketidaktersediaan data pada daerah-daerah pelosok ataupun karena banyaknya kasus yang tidak terdokumentasi (1). Malaria berat umumnya disebabkan oleh Plasmodium falciparum, di mana gejala dari malaria falsiparum biasanya muncul 9-30 hari setelah infeksi (2).

Seperti parasit malaria pada mamalia, Plasmodium berghei yang merupakan plasmodium pada rodensia ditransmisikan oleh nyamuk Anopheles dan menginfeksi hati setelah diinjeksi ke peredaran darah oleh nyamuk betina yang terinfeksi. Setelah beberapa hari perkembangan dan multiplikasi, parasit ini meninggalkan hati dan menginvasi eritrosit. Multiplikasi parasit pada darah menyebabkan patologi seperti anemia dan kerusakan organ esensial dari hospes seperti paru-paru, hati dan limpa . Infeksi Plasmodium berghei dapat juga menyebabkan kerusakan otak dengan menyebabkan komplikasi serebral pada tikus laboratorium. Gejala ini mirip dan analog dengan gejala malaria serebral pada manusia yang terinfeksi Plasmodium falciparum (3). Hemodinamika otak pada malaria serebral kurang begitu jelas dipahami, tetapi beberapa data menunjukkan terjadinya hipoperfusi mikrosirkulasi dan peningkatan aliran darah pada arteri besar. Sekuestrasi terlihat menurunkan perfusi melalui penyempitan diameter lumen pada kapiler terdampak dan menunjukkan gangguan vaskuler dengan derajat keparahan bervariasi pada $44 \%$ tikus percobaan yang menunjukkan vasokonstriksi parah (4). Pada percobaan malaria serebral menunjukkan peningkatan akumulasi sel imun di dalam otak (monosit, makrofag dan sel T). Keterlambatan pengerahan CD8(+) T cells serta produksi molekul sitolitik granzyme B dan perforin sangat berbahaya terkait perkembangan keparahan malaria serebral (5). Heat shock protein 70 kilodalton (HSP70) adalah suatu protein yang diinduksi selama stres protein, yang berperan melindungi sel dari denaturasi dan kematian. Monosit adalah sel yang paling berperan dalam induksi HSP70 (6).

Endoglin (CD105) adalah membran protein integral Tipe 1 dengan domain ekstraseluler besar yaitu 561 asam amino dan juga memiliki domain hidrofobik tunggal transmembran serta domain sitosolik pendek. Terdapat dua isoform yaitu L-endoglin dan S-endoglin, yang terdeteksi pada jaringan manusia dan tikus. Protein Lendoglin dan S-endoglin dibedakan berdasarkan variasi asam amino pada ekor sitoplasmiknya (7). Endoglin terekspresi tinggi pada endotel vaskuler tumor ataupun kanker dan merupakan target vaskular utama yang potensial untuk terapi anti angiogenic kanker. Selain itu endoglin dan betaglycan juga merupakan modulator aktivitas TGF-beta. Transforming growth factor beta (TGFbeta) mempunyai peran penting pada proses fisiologis seperti perkembangan, proliferasi seluler, sintesis matriks ekstraseluler, respon imun dan angiogenesis (8).

Endoglin berada di dalam tubuh dalam dua bentuk yang berbeda, yaitu yang terikat dengan membran sel dan yang bersirkulasi atau sering disebut endoglin terlarut (soluble endoglin). Soluble endoglin (sEng) yang diketahui mampu mengatur sistem imun dan mempengaruhi proses angiogenesis, dilaporkan berkaitan dengan kejadian preeklampsia pada ibu hamil dan keadaan malaria berat pada anak-anak. Dilaporkan juga bahwa sEng berperan penting pada kejadian berat lahir rendah pada penderita malaria plasenta, dan terbukti juga bahwa kejadian malaria pada ibu hamil meningkatkan kadar sEng (9).

Plasmodium falciparum dilaporkan telah mengembangkan resistensi terhadap obat antimalaria, bahkan terhadap artemisinin pada penelitian di Asia Tenggara (10), sehingga diperlukan penemuan obat malaria atau kombinasi terapi malaria yang baru agar pengobatan bisa lebih efektif. Ekstrak metanol batang brotowali mampu menurunkan derajat parasitemia $P$. falciparum galur 3D7 secara in vitro dan merupakan salah satu kandidat untuk pengobatan malaria. Bahan aktif dari ekstrak batang brotowali yang mempunyai aktivitas antimalaria adalah berberin, palmatin, dan tinokrisposid (11). Penelitian ini bertujuan untuk membuktikan bahwa ekspresi HSP70 dan endoglin meningkat pada mencit C57BL/6J yang diinfeksi dengan Plasmodium berghei dibandingkan dengan mencit yang tidak diinfeksi dengan Plasmodium berghei dalam kaitannya dengan malaria serebral eksperimental. Selain itu, juga untuk membuktikan bahwa pemberian artesunat injeksi yang dikombinasikan dengan pemberian ekstrak batang brotowali dapat menurunkan derajat parasitemia lebih baik daripada pemberian terapi tunggal artesunat, dan dapat meningkatkan ekspresi HSP70 dan endoglin.

\section{METODE}

\section{Perlakuan pada Hewan Coba}

Mencit yang digunakan adalah galur C57BL/6J betina karena galur ini lebih rentan terhadap Plasmodium berghei daripada galur lain. Mencit berumur 6-8 minggu dengan berat badan sekitar 20-40 gram yang berasal dari Institut Eijkman Jakarta. Pada kelompok kontrol negatif tidak dilakukan inokulasi Plasmodium berghei ataupun pemberian ekstrak batang brotowali dan artesunat. Pada kelompok kontrol positif dilakukan inokulasi Plasmodium berghei saja. Sedangkan pada kelompok artesunat dilakukan inokulasi Plasmodium berghei, dengan pemberian injeksi artesunat pada hari ke-empat setelah inokulasi dengan dosis $35 \mathrm{mg} / \mathrm{kg}$ berat badan (12). Sedangkan kelompok kombinasi artesunat dan ekstrak batang brotowali dilakukan inokulasi Plasmodium berghei disertai dengan pemberian ekstrak batang brotowali dan injeksi artesunat pada hari ke-empat setelah inokulasi. Dosis ekstrak batang brotowali secara berturut-turut adalah $50 \mathrm{mg}, 60 \mathrm{mg}$, dan $70 \mathrm{mg}$ yang diberikan secara oral menggunakan sonde. Semua kelompok mencit selama penelitian mendapatkan pakan yang normal dan minum ad libitum. Inokulasi Plasmodium berghei dilakukan secara intraperitoneal dengan $5 \times 10^{7}$ sel darah merah yang terinfeksi parasit pada setiap mencit (13). Penelitian ini sudah dilengkapi dengan etik penelitian dari Komisi Etik Penelitian Kesehatan, Fakultas Kedokteran Universitas Brawijaya No. 410/EC/KEPK/07/2014 tertanggal 10 Juli 2014.

\section{Pembuatan Ekstrak Batang Brotowali}

Pembuatan ekstrak batang brotowali diawali dengan mencacah batang brotowali, kemudian dijemur di bawah sinar matahari sampai kering. Batang brotowali kering ditumbuk sampai halus berbentuk serbuk secara manual. Serbuk batang brotowali kemudian dimaserasi menggunakan metanol $90 \%$ selama 24 jam. Proses 
maserasi dilakukan sebanyak 3 kali dan dilakukan penggantian metanol 90\% setiap 24 jam. Selanjutnya, bahan dievaporasi dan dikonsentrasi menggunakan gas N2 (11).

\section{Pengukuran Derajat Parasitemia}

Derajat parasitemia diukur dari pengamatan sediaan apus darah dari ujung ekor mencit sampai hari ke-7, dengan cara: Darah diambil dari ujung ekor mencit yang dilukai dan diteteskan pada gelas obyek, diapus dengan gelas obyek yang lain, dikeringkan pada suhu kamar, kemudian diberi Giemsa \pm 45 menit, dicuci pada air mengalir, lalu dikeringkan pada suhu kamar. Setelah itu diamati di bawah mikroskop perbesaran 1000x dengan minyak emersi. Pemeriksaan pada lapang pandang dengan susunan yang tidak menumpuk, kemudian dihitung eritrosit terinfeksi parasit per 1000 eritrosit (13).

\section{Preparasi Irisan Jaringan Otak untuk Imunohistokimia}

Mencit dieutanasia pada hari ke-7 setelah infeksi dan otaknya diambil dan dipersiapkan untuk pemeriksaan imunohistokimia. Setelah mencit dieutanasia, otak diambil dan diiris dengan ketebalan sekitar $0,5 \mathrm{~cm}$, kemudian dimasukkan ke dalam formalin $10 \%$ sekitar $24-$ 48 jam pada suhu ruang. Selanjutnya, jaringan dicuci dengan air mengalir dari kran sekitar 1 jam. Jaringan didehidrasi dengan alkohol 70\%, 80\%, 95\% masing-masing selama 45 menit, dilanjutkan pada alkohol 100\% dengan 3 kali penggantian alkohol $100 \%$, masing-masing selama 1 jam. Kemudian dilakukan clearing jaringan dengan 2 kali penggantian xylene, masing-masing 1 jam.

Langkah selanjutnya adalah jaringan direndam pada 3 kali penggantian parafin, masing-masing 1 jam. Setelah itu jaringan ditempelkan pada parafin blok dimana dalam bentuk ini jaringan bisa bertahan sangat lama hingga setahun bahkan lebih.Pemotongan parafin blok dengan mikrotom setebal sekitar 5-8 $\mu \mathrm{m}$, kemudian diapungkan pada water bath yang berisi air distilasi hangat dengan suhu sekitar $40^{\circ} \mathrm{C}$. Kemudian potongan jaringan dipindahkan dari water bath ke object glass yang sesuai untuk imunohistokimia. Slide dibiarkan kering semalam dan disimpan pada suhu ruang sampai siap untuk digunakan (14)

Pemeriksaan Imunohistokimia untuk Ekspresi HSP7O dan Endoglin

Prosedur yang digunakan adalah imunohistokimia tidak langsung, yaitu dengan 2 jenis antibodi (primer dan sekunder) dimana antibodi primer yang digunakan adalah antibodi anti-HSP70 dan antibodi anti-endoglin. Satu rangkaian prosedur hanya untuk satu jenis antibodi. Prosedurnya sebagai berikut: Setelah deparafinasi slide dengan xylene sebanyak 3 kali, masing-masing 3 menit, dilanjutkan rehidrasi preparat dengan menggunakan etanol 100\% ( 2 menit), etanol 95\% ( 2 menit), dan etanol 70\% (1 menit) berurutan, kemudian dengan air selama 1 menit. Setelah itu direndam dengan peroxidase blocking protein pada suhu ruang selama 10 menit. Preparat diinkubasi dalam prediluted blocking serum $25^{\circ} \mathrm{C}$ selama 10 menit, preparat direndam di dalam antibodi primer selama 10 menit pada $25^{\circ} \mathrm{C}$, kemudian dicuci dengan phospate buffer saline (PBS) selama 5 menit. Antibodi primer menggunakan antibodi HSP70 produksi Santa Cruz Biotechnology (Texas, USA) dengan nomor katalog sc66048 , serta antibodi mouse endoglin/CD105 produksi R\&D Systems, Inc (Minneapolis, USA) dengan nomor katalog MAB1320. Setelah itu preparat diinkubasi dengan antibodi sekunder (conjugated to horse radish peroxidase) pada $25^{\circ} \mathrm{C}$ selama 10 menit, dicuci dengan PBS selama 5 menit, diinkubasi dengan peroksidase pada $25^{\circ} \mathrm{C}$ selama 10 menit, dicuci dengan PBS selama 5 menit, kemudian diinkubasi dengan kromogen diaminobenzinidine (DAB) $25^{\circ} \mathrm{C}$ selama 10 menit, diinkubasi dengan hematoxylin eosin selama 3 menit, dicuci dengan air mengalir, kemudian dibersihkan dan ditetesi dengan mounting media, setelah itu preparat ditutup dengan cover slip (15).

Pengamatan ekspresi HSP70 ataupun endoglin menggunakan mikroskop cahaya dengan perbesaran 400x, protein HSP70 dan endoglin yang berwarna coklat dihitung per lapang pandang dan diacak pada 5 lapang pandang yang berbeda pada setiap preparat jaringan otak. Setiap pengamatan didokumentasikan (16).

\section{Analisis Data}

Pada data derajat parasitemia dilakukan analisis statistik dengan uji Mann Whitney, dan pada data ekspresi HSP70 dan endoglin dilakukan uji one-way ANOVA dilanjutkan dengan uji post hoc Tukey. Analisis data dilakukan menggunakan software SPSS versi 15.

\section{HASIL}

Penelitian ini dilakukan di Laboratorium Parasitologi dan Laboratorium Biomedik Fakultas Kedokteran Universitas Brawijaya Malang mulai bulan Mei 2014 sampai bulan Januari 2015. Penelitian ini merupakan penelitian in vivo menggunakan mencit galur C57BL/6J yang diinfeksi Plasmodium berghei secara intraperitoneal dengan $5 \times 10^{7}$ sel darah merah yang terinfeksi parasit.

\section{Perbandingan Derajat Parasitemia Berdasarkan Waktu Setelah Infeksi}

Untuk mengetahui perbandingan derajat parasitemia pada setiap kelompok perlakuan, dilakukan uji Mann Whitney pada data mulai dari hari ke-empat sampai hari ke-tujuh setelah infeksi. Penghitungan dimulai dari hari keempat karena pemberian artesunat, ataupun kombinasi artesunat dan ekstrak batang brotowali $(50 \mathrm{mg}, 60 \mathrm{mg}$, dan $70 \mathrm{mg}$ ) diberikan mulai hari ke-empat sampai hari ke-tujuh setelah infeksi (Gambar 1).

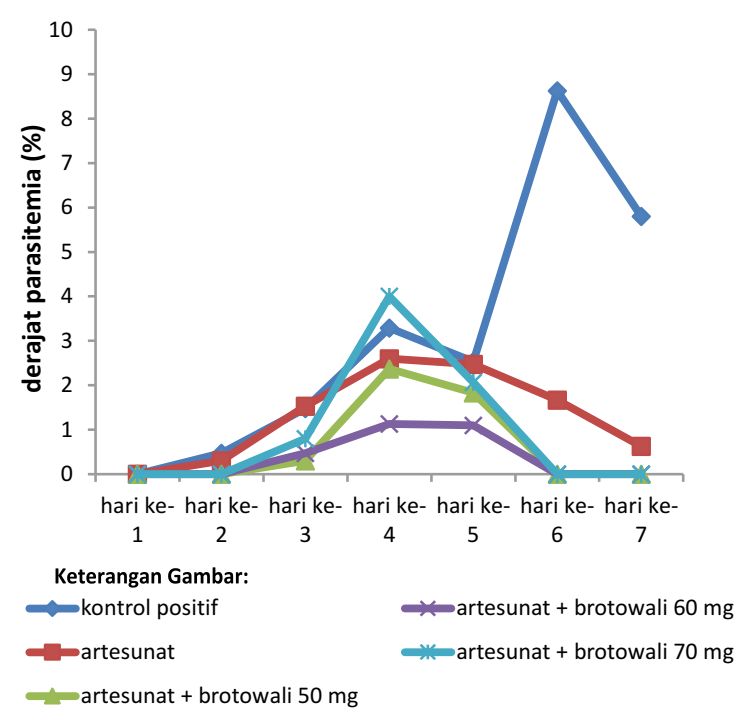

Gambar 1. Derajat parasitemia pada setiap kelompok berdasarkan waktu setelah infeksi 
Tabel 1. Rata-rata derajat parasitemia (\%) setiap kelompok perlakuan dari hari ke-1 sampai hari ke-7

\begin{tabular}{|c|c|c|c|c|c|c|c|}
\hline Perlakuan & Hari ke-1 & Hari ke-2 & Hari ke-3 & Hari ke-4 & Hari ke-5 & Hari ke-6 & Hari ke-7 \\
\hline Kontrol positif & $0,00 \pm 0,00^{a}$ & $0,47 \pm 0,45^{b}$ & $1,48 \pm 0,53^{b}$ & $3,29 \pm 0,47^{c}$ & $2,53 \pm 0,84^{b, c}$ & $8,63 \pm 3,06^{d}$ & $5,80 \pm 6,38^{c}$ \\
\hline Artesunat & $0,00 \pm 0,00^{a}$ & $0,30 \pm 0,44^{b}$ & $1,53 \pm 1,88^{b}$ & $2,60 \pm 3,12^{b, c}$ & $2,47 \pm 2,81^{b, c}$ & $1,67 \pm 1,77^{b}$ & $0,63 \pm 0,15^{b}$ \\
\hline $\begin{array}{l}\text { Artesunat+ } \\
\text { brotowali } 50 \mathrm{mg}\end{array}$ & $0,00 \pm 0,00^{a}$ & $00,0 \pm 0,00^{a}$ & $0,30 \pm 0,20^{b}$ & $2,37 \pm 2,90^{b}$ & $1,83 \pm 0,15^{b}$ & $0,00 \pm 0,00^{a}$ & $0,00 \pm 0,00^{a}$ \\
\hline $\begin{array}{l}\text { Artesunat+ } \\
\text { brotowali } 60 \mathrm{mg}\end{array}$ & $0,00 \pm 0,00^{a}$ & $00,0 \pm 0,00^{a}$ & $0,47 \pm 0,32^{b}$ & $1,13 \pm 1,01^{b}$ & $1,10 \pm 0,60^{b}$ & $0,00 \pm 0,00^{a}$ & $0,00 \pm 0,00^{a}$ \\
\hline $\begin{array}{l}\text { Artesunat+ } \\
\text { brotowali } 70 \mathrm{mg}\end{array}$ & $0,00 \pm 0,00^{a}$ & $00,0 \pm 0,00^{a}$ & $0,80 \pm 0,53^{b}$ & $4,00 \pm 0,62$ & $2,07 \pm 0,50$ & $0,00 \pm 0,00^{a}$ & $0,00 \pm 0,00^{a}$ \\
\hline
\end{tabular}

Tabel 2. Rata-rata jumlah sel per lapang pandang yang mengekspresikan HSP70 berdasarkan analisis one-way ANOVA

\begin{tabular}{lcc}
\hline Perlakuan & $\begin{array}{c}\text { Ekspresi HSP70 } \\
\text { (mean } \pm \text { SD) (\%) }\end{array}$ & Peningkatan \\
\hline Kontrol Negatif & $13,13 \pm 1,01^{\mathrm{a}}$ & \\
Kontrol Positif & $17,43 \pm 0,60^{\mathrm{b}}$ & $32,74 \%$ \\
Artesunat & $20,93 \pm 1,10^{\mathrm{c}}$ & $59,39 \%$ \\
Artesunat + brotowali $50 \mathrm{mg}$ & $22,47 \pm 1,33^{\mathrm{c}}$ & $71,07 \%$ \\
Artesunat + brotowali $60 \mathrm{mg}$ & $28,53 \pm 1,60^{\mathrm{d}}$ & $117,26 \%$ \\
Artesunat + brotowali $70 \mathrm{mg}$ & $21,13 \pm 1,10^{\mathrm{c}}$ & $60,91 \%$ \\
\hline
\end{tabular}

Keterangan: Notasi huruf yang berbeda menunjukkan perbedaan yang signifikan $(p<0,05)$.

Diketahui bahwa rata-rata ekspresi HSP70 paling tinggi adalah pada perlakuan kombinasi artesunat dan brotowali $60 \mathrm{mg}$, sedangkan rata-rata ekspresi paling rendah adalah pada perlakuan kontrol negatif. Berdasarkan uji one-way Anova, ekspresi HSP70 pada kontrol negatif menunjukkan perbedaan yang signifikan $(p<0,05)$ terhadap semua perlakuan yang lain, demikian juga dengan kontrol positif menunjukkan hal yang serupa. Kelompok artesunat menunjukkan perbedaan yang signifikan $(p<0,05)$ terhadap kontrol negatif, kontrol positif, dan kelompok kombinasi artesunat dan brotowali $60 \mathrm{mgi}$, tetapi tidak berbeda signifikan $(p \geq 0,05)$ terhadap kelompok kombinasi artesunat dan brotowali $50 \mathrm{mg}$ dan $70 \mathrm{mg}$ (Tabel 2, Gambar 2).
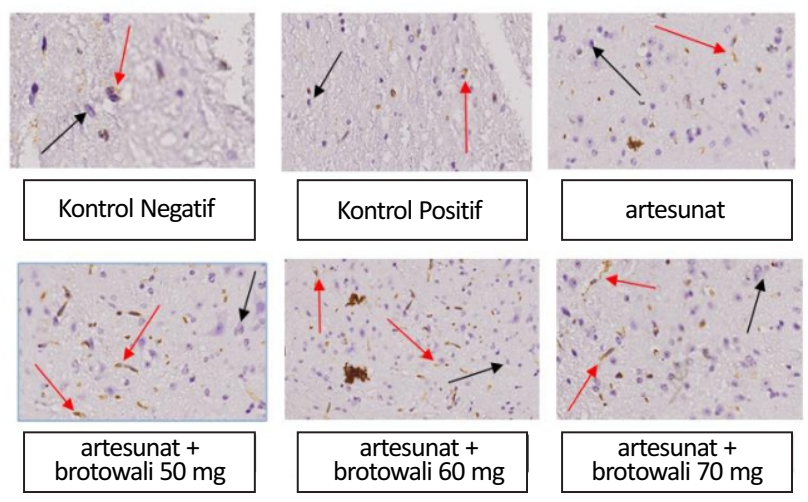

Gambar 2. Ekspresi HSP70 pada setiap kelompok perlakuan
Keterangan: Ekspresi HSP70 pada jaringan otak mencit C57BL/6J yang diinfeksi Plasmodium berghei dengan pewarnaan imunohistokimia ditunjukkan dengan tanda panah warna merah. Tanda panah warna hitam menunjukkan sel otak mencit yang tidak mengekspresikan HSP70. Tampak ekspresi HSP70 pada kelompok kombinasi artesunat dan brotowali lebih banyak dibanding kelompok kontrol atau kelompok artesunat. Perbesaran 400x dengan mikroskop Olympus Cx31.

Tabel 3. Rata-rata jumlah sel per lapang pandang yang mengekspresikan endoglin berdasarkan analisis one-way ANOVA

\begin{tabular}{lll}
\hline Perlakuan & $\begin{array}{c}\text { Ekspresi Endoglin } \\
\text { (mean } \pm \text { SD) (\%) }\end{array}$ & Peningkatan \\
\hline Kontrol Negatif & $5,33 \pm 1,50^{\mathrm{a}}$ & \\
Kontrol Positif & $8,47 \pm 2,20^{\mathrm{a}, \mathrm{b}}$ & $58,75 \%$ \\
Artesunat & $9,93 \pm 1,80^{\mathrm{a}, \mathrm{b}}$ & $86,25 \%$ \\
Artesunat + brotowali $50 \mathrm{mg}$ & $11,87 \pm 3,16^{\mathrm{b}}$ & $122,50 \%$ \\
Artesunat + brotowali $60 \mathrm{mg}$ & $14,20 \pm 2,12^{\mathrm{b}}$ & $166,25 \%$ \\
Artesunat + brotowali $70 \mathrm{mg}$ & $10,80 \pm 1,20^{\mathrm{b}}$ & $102,50 \%$ \\
\hline
\end{tabular}

Keterangan: Notasi huruf yang berbeda menunjukkan perbedaan yang signifikan $(p<0,05)$.

Diketahui bahwa rata-rata ekspresi endoglin paling tinggi adalah pada perlakuan kombinasi artesunat dan brotowali $60 \mathrm{mg}$, sedangkan rata-rata ekspresi paling rendah adalah pada kelompok kontrol negatif. Berdasarkan hasil analisis statistik one-way ANOVA, ekspresi endoglin pada kontrol negatif menunjukkan perbedaan yang tidak signifikan $(p \geq 0,05)$ terhadap kelompok kontrol positif dan kelompok artesunat, tetapi berbeda signifikan $(p<0,05)$ terhadap kelompok kombinasi artesunat dan brotowali $(50 \mathrm{mg}$, $60 \mathrm{mg}$, dan 70mg). Pada kontrol positif menunjukkan perbedaan yang tidak signifikan $(p \geq 0,05)$ terhadap semua kelompok yang lainnya, begitu juga dengan kelompok artesunat. Kelompok kombinasi artesunat dan brotowali (50mg, 60mg, dan 70mg) hanya menunjukkan perbedaan yang signifikan $(p<0,05)$ terhadap kontrol negatif. Secara keseluruhan ekspresi HSP70 pada preparat otak mencit C57BL/6J lebih besar daripada ekspresi endoglin. Ekspresi terbesar dari HSP70 dan endoglin sama-sama muncul pada perlakuan kelompok kombinasi artesunat dan brotowali60mg (Tabel 3, Gambar 3). 


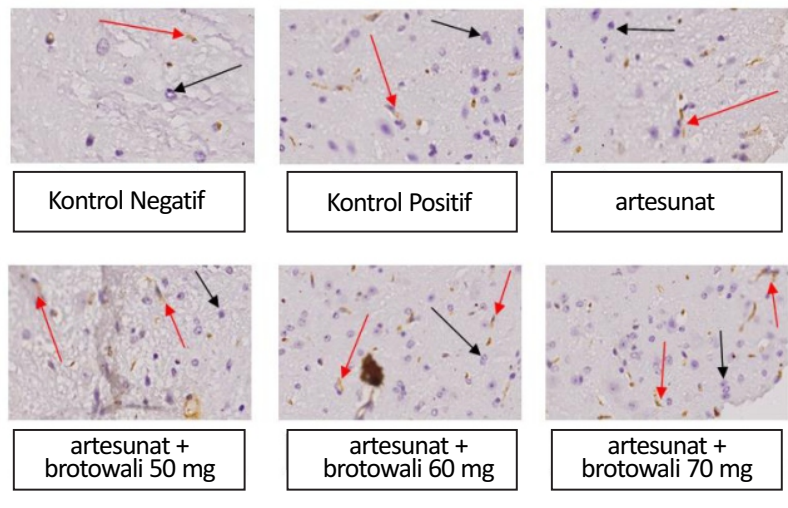

Gambar 3. Ekspresi endoglin pada setiap kelompok perlakuan Keterangan: Ekspresi endoglin pada preparat otak mencit C57BL/6J yang diinfeksi Plasmodium berghei dengan pewarnaan imunohistokimia ditunjukkan dengan tanda panah warna merah. Tanda panah warna hitam menunjukkan sel otak mencit yang tidak mengekspresikan endoglin. Tampak ekspresi endoglin pada kelompok kombinasi lebih banyak dibanding kontrol ataupun kelompok artesunat. Perbesaran 400x dengan mikroskop Olympus CX31.

\section{DISKUSI}

Efek Kombinasi Artesunat dan Ekstrak Batang Brotowali dalam Menurunkan Derajat Parasitemia

Dari penelitian ini diketahui bahwa kelompok perlakuan kontrol positif cenderung mengalami peningkatan derajat parasitemia sampai hari ke-6 yaitu sebesar $8,63 \%$ dan sedikit menurun pada hari ke-7 yaitu 5,80\%. Sedangkan dengan pemberian perlakuan artesunat pada hari ke-4 setelah infeksi diketahui derajat parasitemia terus menurun sampai pada hari ke-7 setelah infeksi, mencapai $0,63 \%$. Hal ini sesuai dengan publikasi WHO pada tahun 2010 yang menyebutkan bahwa artesunat dan derivat artemisinin lainnya mempunyai kemampuan yang cepat dalam membersihkan parasitemia dibandingkan dengan obat antimalaria lain yang tersedia saat ini. Mekanisme kerja artesunat sebagai antimalaria yaitu melalui proses produksi radikal bebas pada vakuola makanan Plasmodium, dan penghambatan pada kerja kalsium ATPase pada sel parasit. Keuntungan utama dari antimalaria kelas artemisin adalah rapid antiparasitic activity, serta mampu melawan semua fase infeksi parasit di eritrosit, termasuk pada fase gametosit, sehingga menimbulkan manfaat klinis yang cepat (17).

Dari penelitian ini juga didapatkan hasil bahwa derajat parasitemia dikendalikan lebih baik menggunakan kombinasi terapi antara artesunat dengan ekstrak batang brotowali dibandingkan dengan terapi tunggal menggunakan artesunat saja. Dengan menggunakan terapi kombinasi artesunat dan ekstrak batang brotowali (50 mg, 60 mg, $70 \mathrm{mg}$ ) derajat parasitemia mencapai 0\% pada hari ke-6. Ekstrak brotowali terbukti memiliki efek antimalaria terhadap Plasmodium yoelii (18). Ekstrak etanol dari brotowali juga terbukti memperbaiki dan mengoptimalkan ekspresi sitokin intraseluler, INF- $\gamma$, IL-6, dan IL-8 (19). Bahan aktif dari ekstrak batang brotowali yang mempunyai aktivitas antimalaria adalah berberin, palmatin, dan tinokrisposid. Berberin sendiri adalah komponen yang mengandung senyawa alkaloid yang struktur kimianya mengandung quaternary nitrogen yang kemudian diketahui mampu menghambat pertumbuhan
Plasmodium dengan menghambat tranportasi intraseluler darikolin (11).

Selain itu, diketahui juga bahwa terapi kombinasi artesunat dan ekstrak batang brotowali $60 \mathrm{mg}$ paling baik menurunkan derajat parasitemia jika dibandingkan dengan terapi kombinasi artesunat dan ekstrak batang brotowali $50 \mathrm{mg}$ ataupun $70 \mathrm{mg}$. Hal ini membuktikan bahwa kombinasi bahan aktif keduanya saling memperkuat secara maksimal pada dosis brotowali $60 \mathrm{mg}$ dalam mengendalikan derajat parasitemia ataupun menghilangkan agen parasit. Sehingga efektivitas terapi kombinasi tidak semakin baik pada dosis brotowali yang semakin besar akan tetapi mencapai optimal pada dosis 60 mg. Penelitian tentang farmakokinetik ataupun farmakodinamik perlu dilakukan untuk bisa menjawab kenapa pada dosis brotowali $70 \mathrm{mg}$ efektivitas terapi tidak lebih baik daripada dosis brotowali $60 \mathrm{mg}$.

\section{Efek Kombinasi Artesunat dan Ekstrak Batang Brotowali dalam Meningkatkan Ekspresi HSP7O}

Berdasarkan penghitungan ekspresi protein HSP70 dari preparat imunohistokimia jaringan otak mencit perlakuan diketahui bahwa pemberian artesunat ataupun kombinasi artesunat dan ekstrak batang brotowali $(50 \mathrm{mg}, 60 \mathrm{mg}$, dan $70 \mathrm{mg}$ ) terbukti meningkatkan ekspresi HSP70. Rata-rata ekspresi HSP70 pada kontrol positif $(17,43 \pm 0,60)$ lebih rendah daripada kelompok artesunat $(20,93 \pm 1,10)$, kelompok kombinasi artesunat dan brotowali $50 \mathrm{mg}(22,47$ $\pm 1,33)$, kelompok artesunat dan brotowali $60 \mathrm{mg}(28,53 \pm$ $1,60)$, ataupun dari kelompok artesunat dan brotowali 70 $\mathrm{mg}(21,13 \pm 1,10)$. Mekanisme kenapa hal ini terjadi perlu diteliti lebih lanjut, tetapi diperkirakan meningkatnya ekspresi HSP70 terjadi karena pemberian artesunat ataupun kombinasi artesunat dan ekstrak batang brotowali memicu sel otak untuk mengaktifkan HSP70 yang berhubungan dengan fungsinya sebagai protein yang bekerja melindungi sel dari kerusakan ataupun dampak buruk dari iskemia serebral.

Malaria serebral berkaitan dengan sekuestrasi sel darah merah yang terinfeksi Plasmodium pada mikrovaskuler otak yang kadang diikuti obstruksi ataupun mikrohemoragi. Proporsi pembuluh darah otak yang berisi eritrosit terinfeksi bisa mencapai 100\%. (20). Sekuestrasi sel darah merah di dalam mikrovaskuler dapat meningkatkan volume serebral, bersamaan dengan peningkatan aliran darah serebral karena seizure, anemia, dan hipertermia, maka akan memicu edema serebral, kemudian meningkatkan tekanan intrakranial yang dapat mengakibatkan kerusakan otak maupun kematian (21). Heat shock protein 70 kilodalton (HSP70) merupakan protein penting yang berperan dalam melindungi sel dari kerusakan akibat stres dan juga merupakan indikator stres protein pada kejadian iskemia serebral. Selain itu, juga terbukti bahwa ekspresi HSP70 pada tikus transgenik secara nyata melindungi otak tikus dari focal ischemic infarction dan secara moderat melindunginya dari global ischemic injury (6).

\section{Efek Kombinasi Artesunat dan Ekstrak Batang Brotowali dalam Meningkatkan Ekspresi Endoglin}

Berdasarkan penghitungan ekspresi endoglin dari preparat imunohistokimia jaringan otak mencit diketahui bahwa pemberian artesunat, ataupun pemberian kombinasi artesunat dan ekstrak batang brotowali $(50 \mathrm{mg}$, $60 \mathrm{mg}$, dan $70 \mathrm{mg}$ ) terbukti juga meningkatkan ekspresi 
endoglin. Rata-rata ekspresi endoglin pada kontrol positif $(8,47 \pm 2,20)$ lebih rendah daripada kelompok artesunat $(9,93 \pm 1,80)$, kelompok artesunat dan brotowali $50 \mathrm{mg}$ $(11,87 \pm 3,16)$, kelompok artesunat dan brotowali $60 \mathrm{mg}$ $(14,20 \pm 2,12)$, ataupun dari kelompok artesunat dan brotowali $70 \mathrm{mg}(10,80 \pm 1,20)$. Pada malaria serebral eksperimental terjadi hipoksia otak akibat iskemia (20). Selain itu, ekspresi endoglin diketahui meningkat selama infark miokardial (22). Endoglin diketahui memodulasi fungsi dari TGF $\beta$ dan ekspresinya mempengaruhi respon TGF $\beta$ melalui modulasi proses seluler penting, diantaranya proliferasi, diferensiasi, dan migrasi (8). Fungsi dari TGF $\beta$ diantaranya sebagai penghambat proliferasi sel epitel secara normal, memelihara arsitektur jaringan, menginduksi apoptosis, serta berperan dalam sistem imun dan peradangan (23).

Mekanisme molekuler yang terlibat di dalam patogenesis malaria serebral belum diketahui secara jelas dan pasti. Transforming growth factor beta (TGF-beta) merupakan regulator penting pada inflamasi dan patogenesis malaria.Bentuk terlarut dari endoglin (sENG) kemungkinan berperan penting dalam patogenesis malaria berat (24). Endoglin signaling pathway diketahui diaktivasi pada sel endotelial ketika terjadi hipoksia, selain itu ekspresi endoglin terbukti meningkat pada keadaan infark (22). Ekspresi TGF- $\beta 1$ dan keadaan hipoksia diketahui dapat menginduksi upregulation gen promotor endoglin (25). Riset terdahulu juga menunjukkan bahwa produksi sitokin terbukti berperan dalam mencegah dan memperbaiki keadaan iskemia jaringan pada hewan model stroke (26).

Endoglin mempunyai kemampuan mengatur infiltrasi makrofag dan produksi sitokin pada ginjal mencit yang diiradiasi (27). Dari penelitian ini didapatkan hasil bahwa ekspresi endoglin meningkat signifikan pada perlakuan

\section{DAFTAR PUSTAKA}

1. Nayyar GML, BremanJG, Newton PN, and Herrington J. Poor-quality antimalarial drugs in southeast Asia and sub-Saharan Africa. The Lancet Infectious Diseases. 2012; 12(6): 488-496.

2. Bartoloni A and Zammarchi L. Clinical aspectsof uncomplicatedand severe malaria. Mediterranian Journal of Hematology and Infectious Diseases.2012; 4(1): e2012026.

3. Franke-Fayard B, Fonager J, Braks A, Khan SM, and Janse CJ. Sequestration and Tissue Accumulation of Human Malaria Parasites: Can We Learn Anything from Rodent Models of Malaria? PLoS Pathogens. 2010; 6(9): 50-65.

4. Cabrales P, Zanini GM, Frangos JA, and Carvalho LJ. Murine Cerebral Malaria is Associated with a Vasospasm-Like Microcirculatory Dysfunction, and Survival Upon Rescue Treatment is Markedlyincreased by Nimodipine. The American Journal of Pathology. 2010; 176(3): 1306-1315.

5. Hague A, Best SE, Unosson K, et al. Granzyme $B$ Expression By CD8+ T Cells is Required for the Development of Experimental Cerebral Malaria. Journal of Immunology. 2011; 186(11): 6148-6156.

6. Madden J, Coward JC, Shearman CP, Grimble RF, and kelompok artesunat ataupun kelompok kombinasi artesunat dan ekstrak batang brotowali dibandingkan dengan kelompok kontrol. Mekanisme bagaimana artesunat ataupun kombinasi artesunat dan ekstrak batang brotowali bisa meningkatkan ekspresi endoglin pada malaria serebral eksperimental memang perlu penelitian lebih lanjut, tetapi diperkirakan hal ini berkaitan dengan imunitas mencit. Diperkirakan artesunat dan brotowali memicu peningkatan ekspresi endoglin dalam kaitannya meningkatkan infiltrasi makrofag dan produksi sitokin dalam menghadapi agen parasit ataupun membersihkan sel-sel yang rusak akibat aktivitas parasit (12). Selain memfagosit sel yang mati, makrofag juga mampu menelan patogen dalam proses fagositosis serta berperan penting dalam imunitas adaptif.

Dari penelitian ini bisa disimpulkan bahwa ekspresi HSP70 meningkat pada mencit C57BL/6J yang diinfeksi dengan Plasmodium berghei dibandingkan dengan mencit yang tidak diinfeksi dengan Plasmodium berghei dalam kaitannya dengan malaria serebral eksperimental. Peningkatan ekspresi HSP70 tertinggi sebesar 117,26\% terjadi pada dosis brotowali $60 \mathrm{mg}$. Ekspresi endoglin meningkat pada mencit C57BL/6J yang diinfeksi dengan Plasmodium berghei dibandingkan dengan mencit yang tidak diinfeksi dengan Plasmodium berghei dalam kaitannya dengan malaria serebral eksperimental. Peningkatan ekspresi endoglin tertinggi sebesar 166,25\% terjadi pada dosis brotowali $60 \mathrm{mg}$. Selain itu pemberian artesunat injeksi yang dikombinasikan dengan pemberian ekstrak batang brotowali terbukti dapat menurunkan derajat parasitemia lebih baik daripada pemberian terapi tunggal artesunat dan pada dosis brotowali 60 mgmenunjukkan efektivitas terbaik dengan menurunkan derajat parasitemia menjadi $1,10 \%$ pada hari ke-5 dan $0 \%$ pada hari ke-6.

Calder PC. Hsp70 expression in monocytes from patients with peripheral arterial disease and healthy controls: monocyte Hsp70 in PAD. Cell Biology Toxicology. 2010; 26(3): 215-223.

7. Blanco FJ and Barnebeu C. Alternative Splicing Factor or Splicing Factor-2 Plays a Key Role in Intron Retention of the Endoglin Gene during Endothelial Senescence. Aging Cell Journal. 2011; 10(5): 896-907.

8. Barnebeu C, Lopez-Novoa JM, and Quintanila M. The Emerging Role of TGF-Beta Superfamily Coreceptors in Cancer. Biochimica et Biophysica Acta. 2009; 1792(10): 954-973.

9. Silver KL, Conroy AL,Leke RG, Gwanmesia P, Molyneux ME, Taylor DW, Rogerson SJ, and Kain KC. Circulating solubleendoglin levels in pregnant women in Cameroon and Malawi-associations with placental malaria and fetal growth restriction. PLoS ONE. 2011; 6(9):e24985.

10. Hawkes M, Conroy AL,and Kain KC. Spread of artemisinin resistance in malaria. The New England Journal of Medicine. 2014; 371: 1944-1945.

11. Ihwan, Rifa'i M, dan Fitri LE. Antiplasmodial test of Tinospora crispa stem extract against Plasmodium falciparum 3D7 strain in vitro. Jurnal Kedokteran Brawijaya. 2014; 28(2): 91-96. 
12. Miranda AS, Brant F, Rocha NP, Cisalpino D, Rodrigues DH, Souza DG, Machado FS, Rachid MA, Teixeira AL $\mathrm{Jr}$, and Campos AC. Further evidence for an antiinflammatory role of artesunate in experimental cerebral malaria. Malaria Journal. 2013; 12: 388.

13. Okokon JE, Ettebong $\mathrm{E}$, and Antia BS.In vivo antimalarial activity of ethanolic leaf extract of Stachytarpheta cayennensis. Indian Journal of Pharmacology. 2008; 40(3): 111-113.

14. Biolegend.Immunohistochemistry protocol for paraffin-embedded sections. (Online), 3 Mei 2008. http://www.biolegend.com/media_assets/support _protocol/BioLegend_IHC_Paraffin.pdf. [Diakses pada 15/10/2014].

15. Cancer Chemoprevention Research Center Fakultas Farmasi UGM.Prosedur tetap pengecatan imunohistokimia p53. (Online),4 Juni 2014.http://ccrc.farmasi.ugm.ac.id/wpcontent/uploads/sop-ihc-p53-laras.pdf. [Diakses pada 15/10/2014].

16. Suarsana IN, Wresdiyati T, dan Suprayogi A. Respon stres oksidatif dan pemberian isoflavon terhadap aktivitas enzim superoksida dismutase dan peroksidasi lipid pada hati tikus. Indonesian Journal of Animal and Veterinary Sciences. 2013; 18(2): 146152.

17. Seth SD and Seth V. Textbook of pharmacology. 3rd Ed. New Delhi: Elsevier India; 2009; pp. 80-88.

18. Rungruang $T$ and Boonmars T. In Vivo Antiparasitic Activity of the Thai Traditional Medicine Plant-Tinospora Crispa--Against Plasmodium yoelii. The Southeast Asian Journal of Tropical Medicine Public Health. 2009; 40(5): 898-900.

19. Abood WA, Fahmi I, Abdulla MA, and Ismail S. Immunomodulatory Effect of an Isolated Fraction from Tinospora Crispa on Intracellular Expression of INF- $\Gamma$, IL-6, and IL-8. BMC Somplementary and Alternative Medicine. 2014; 14: 200-213.
20. Craig AG, Grau GE, Janse C, et al. The Role of Animal Models for Research on Severe Malaria. PLoS Pathogen. 2012; 8(2): 233-254

21. Jain K, Sood S, and Gowthamarajan K. Modulation of cerebral malaria by curcumin as an adjunctive therapy.Brazilian Journal of Infectious Diseases. 2013; 17(5): 571-591.

22. Tian F, Zhou AX, Smits AM, et al. Endothelial Cells are Activated During Hypoxia Via Endoglin/ALK1/SMAD1/5 Signaling In Vivo and In Vitro. Biochemical and Biophysical Research Communications. 2010; 392(3): 283-288.

23. Rosman DS. Role of TGF-Beta Variant in Breast Cancer. [Dissertation]. Northwestern University, Evanston. 2008.

24. Dietmann A, Helbok R, Lackner P, et al. Endoglin in African Children with Plasmodium falciparum Malaria: A Novel Player in Severe Malaria Pathogenesis? The Journal of Infectious Diseases. 2009; 200(12): 1842-1848.

25. Nassiri F, Cusimano MD, Scheithauer BW, et al. Endoglin (CD105): A Review of its Role in Angiogenesis and Tumor Diagnosis, Progression and Therapy. Anticancer Research. 2011; 31(6): 22832290.

26. Zhao J, Mou Y, Bernstock JD, et al. Synthetic Oligodeoxynucleotides Containing Multiple Telemeric TTAGGG Motifs Suppress Inflammasome Activity in Macrophages Subjected to Oxygen and Glucose Deprivation and Reduce Ischemic Brain Injury in Stroke-Prone Spontaneously Hypertensive Rats. PloS ONE. 2015; 10(10): 1-17.

27. Scharpfenecker M, Floot B, Russell NS, and Stewart FA. The TGF-B Co-Receptor Endoglin Regulates Macrophage Infiltration and Cytokine Production in the Irradiated Mouse Kidney. Radiotherapy and Oncology. 2012; 105(3):313-320. 